\title{
Upolitycznienie sportu jako następstwo konfrontacji politycznej państw
}

\begin{abstract}
Streszczenie: Artykuł poświęcony jest zjawisku wzajemnego oddziaływania na siebie światów portu i polityki. Jego celem jest eksploracja przejawów sprzężeń pomiędzy polityką a sportem w sytuacjach występowania konfliktu pomiędzy państwami. Podjęta została próba wskazania sposobów przenoszenia rywalizacji politycznej na grunt sportu, a także celów i uwarunkowań z nimi związanych.

Analizie zostały poddane następujące sposoby przenoszenia do świata sportu politycznej konfrontacji pomiędzy państwami: rywalizacja w klasyfikacji medalowej igrzysk olimpijskich, rywalizacja związana z prestiżowymi starciami sportowymi, organizacja imprez sportowych, udział w międzynarodowej rywalizacji sportowej oraz bojkot sportowy.

W wyniku badania zauważono, iż nadawanie politycznego znaczenia sportowi w sytuacji konfrontacji politycznej państw może być związane z chęcią podniesienia własnego prestiżu oraz uderzenia $\mathrm{w}$ innych aktorów stosunków międzynarodowych. Zauważono ponadto, iż państwa niedemokratyczne mają szczególną tendencję do wykorzystywania sportu w celach politycznych.
\end{abstract}

Słowa kluczowe: upolitycznienie sportu, sport, polityka, konfrontacja polityczna

$\mathbf{W}$ dzisiejszych czasach sport stał się jednym z bardziej ekscytujących zagadnień. Mimo, że powstał w nowoczesnej, rywalizacyjnej formie stosunkowo niedawno, gdyż jego początki wiązane są z drugą połową XIX wieku, bardzo szybko zyskiwał na popularności, głównie za sprawą powstania w 1894 r. Międzynarodowego Komitetu Olimpijskiego i organizowanych przez niego od 1896 r. w cyklu czteroletnim igrzysk olimpijskich. Popularność ta wzrastała szczególnie od lat trzydziestych XX wieku oraz po zakończeniu II wojny światowej. Rosnącą popularność sportu można było zaobserwować chociażby na przykładzie większego zainteresowania, jakie temu zjawisku poświęcała prasa. I tak w brytyjskiej gazecie „People” w okresie międzywojennym sportowi poświęcano 4 strony, podczas gdy kilka lat po wojnie na zagadnienia związane z rywalizacją sportową przeznaczano już 1/3 wydań. Bardzo znacząco rósł jednocześnie nakład: w 1924 r. wynosił 600000 egzemplarzy, podczas gdy w 1946 r. już 4600000 . Także inne brytyjskie gazety poświęcały coraz więcej miejsca sportowi, takie jak „News of the World”, „Daily Mail” czy „Daily Express” (Holt, 1992, s. 309). Rosła także liczba państw biorących udział w międzynarodowej rywalizacji sportowej. Od 1945 r. do początku lat osiemdziesiątych liczba Narodowych Komitetów Olimpijskich wzrosła o 202,1\%, międzynarodowych federacji o 48,5\%, a łącznie międzynarodowych organizacji i federacji o 60\% (Młodzikowski, 1981, s. 41). Ten dynamiczny wzrost można częściowo wiązać z procesem dekolonizacji i z faktem, iż na scenie międzynarodowej pojawiało się coraz więcej aktorów państwowych. Jednak właściwie wszystkie z nich 
w mniej lub bardziej pełny sposób biorą udział w światowym sporcie, co może świadczyć o uniwersalności tego zjawiska. O dzisiejszej popularności sportu może z kolei świadczyć ilość widzów, którzy oglądają w telewizji poszczególne wydarzenia sportowe. Szacuje się zatem, iż ceremonię otwarcia letnich igrzysk olimpijskich w Londynie w 2012 roku oglądało na ekranach telewizorów 900 mln ludzi (London), natomiast spośród cieszących się największą oglądalnością wydarzeń sportowych w Polsce należy wskazać mecz otwarcia rozgrywanych w Polsce i na Ukrainie mistrzostw Europy w piłce nożnej pomiędzy Polską i Grecją, który obejrzało 15,5 mln widzów oraz konkurs skoków narciarskich z igrzysk olimpijskich w Salt Lake City w 2002 roku - 14,5 mln widzów (TVP). Właśnie dzięki tak wielkiej popularności sport stał się jedną z ważnych sfer zainteresowania wielu dziedzin. Gwiazdy światowego sportu są świetnie opłacane za reklamowanie różnego rodzaju produktów, natomiast wydarzenia sportowe należą do najchętniej oglądanych transmisji telewizyjnych, a zatem organizatorzy imprez sportowych oraz federacje sportowe świetnie zarabiają na sprzedaży praw transmisyjnych.

Przedmiotem badań podjętych w niniejszym artykule jest zjawisko wzajemnego oddziaływania na siebie światów sportu i polityki, które bywa określane jako upolitycznienie sportu bądź polityka sportu. Celem artykułu jest zatem eksploracja przejawów sprzężeń pomiędzy polityką a sportem związanych z konfrontacją polityczną państw. Należy w związku z tym nadmienić, iż sport może odgrywać polityczną rolę zarówno w kontekście budowania zgody, jak i konfrontacji politycznej (Bloyce, Smith, 2010, s. 30), niniejszy artykuł odnosi się natomiast do problemu badawczego dotyczącego tego, w jaki sposób rywalizacja polityczna może być przenoszona na z pozoru apolityczny grunt sportu. Podjęta zostanie w związku z tym próba odpowiedzi na pytania badawcze dotyczące celów oraz uwarunkowań przenoszenia na areny sportowe konfrontacji politycznej.

Niniejsze badanie ma charakter empiryczny i obejmuje pięć studiów przypadku dotyczących wyodrębnionych przejawów sprzężeń pomiędzy polityką a sportem, związanych z międzynarodowymi waśniami. Poszczególne casusy stanowią grunt dla formułowania generalizacji odnośnie upolitycznienia sportu. Analizowane przypadki zostały selekcjonowane przy wykorzystaniu techniki wyboru przypadków typowych. Należy nadmienić, iż intencją autora nie jest stworzenie klasyfikacji przejawów upolitycznienia sportu. Jest to bowiem na tyle szeroki i zróżnicowany przedmiot badań, iż nie byłaby ona wyczerpująca.

Struktura artykułu obejmuje pięć części merytorycznych, każda poświęcona analizie innego sposobu przenoszenia do świata sportu politycznej konfrontacji pomiędzy państwami. Dwie pierwsze części związane są z politycznym znaczeniem międzynarodowej rywalizacji sportowej - odpowiednio w związku z dążeniem do uzyskania jak największej liczby medali podczas igrzysk olimpijskich oraz uzyskiwania zwycięstw podczas konkretnych wydarzeń sportowych, które z różnych względów traktowane są jako prestiżowe. W dalszej części analiza obejmuje kwestię organizacji imprez sportowych, co ma znaczenie przede wszystkim w kontekście podkreślania prestiżu gospodarza danego wydarzenia. Czwarty przejaw upolitycznienia sportu związany jest z politycznym znaczeniem udziału w międzynarodowej rywalizacji sportowej przez poszczególne państwa, zaś wieńcząca artykuł cześć czwarta związana jest z bojkotem sportowym, a zatem jednym z najbardziej medialnych przejawów przenoszenia do świata sportu politycznych waśni. 


\section{Rywalizacja w klasyfikacji medalowej igrzysk olimpijskich}

Pierwsze dwie części merytoryczne związane są z rywalizacją czysto sportową, której nadawano znaczenie polityczne, zgodnie z założeniem, iż sukcesy w sporcie przyczyniają się do implementacji pozasportowych celów państwa (Hoye, Nicholson, Houlihan, 2010, s. 1). Jako pierwsza przedstawiona zostanie kwestia nadawania politycznego znaczenia współzawodnictwu sportowemu pomiędzy państwami. - na przykładzie rywalizacji o zdobycie jak największej liczby medali podczas uznawanych za najważniejszą imprezę sportową igrzysk olimpijskich. Oczywiście tabele medalowe można konstruować także podczas innych wydarzeń multisportowych, czyli obejmujących rywalizację $\mathrm{w}$ więcej niż jednej dyscyplinie, jednak rola igrzysk olimpijskich jest w tym kontekście szczególna.

Poniższa analiza dotyczy w szczególności letnich igrzysk olimpijskich. Klasyfikacja medalowa to zestawienie wszystkich medali, jakie dana reprezentacja zdobyła podczas danej imprezy sportowej. Zazwyczaj w pierwszej kolejności brane są pod uwagę medale złote, w drugiej srebrne, w trzeciej zaś brązowe, choć występują także wyjątki od tej reguły, jednak raczej o charakterze lokalnym. O klasyfikacji medalowej igrzysk olimpijskich można powiedzieć, iż najpełniej oddaje poziom sportowy poszczególnych państw. Pojedyncze zwycięstwo sportowe może bowiem być związane z szeregiem przypadkowych okoliczności. Tymczasem na wynik danego państwa w klasyfikacji medalowej wpływa szereg elementów. Badania wskazują, iż należą do nich w szczególności wielkość populacji danego kraju, dochód na osobę, przewaga z faktu bycia gospodarzem danej imprezy sportowej oraz system polityczny (Bian, 2005, s. 37-38). Elementy te, co oczywiste, równie dobrze mogłyby być użyte jako determinanty ogólnej potęgi państwa, co wydaje się potwierdzać przypuszczenie zakładające, iż klasyfikacja medalowa igrzysk olimpijskich może być postrzegana jako w pewnym sensie „odbicie” potęgi państwa.

Należy zwrócić uwagę, iż nie zawsze klasyfikacja medalowa igrzysk olimpijskich była wykorzystywana do politycznego udowadniania wyższości jednych państw od drugich. Po raz pierwszy nabrała ona takiego znaczenia dopiero w 1936 r. podczas organizowanych przez III Rzeszę igrzysk w Berlinie. Sprawność fizyczna należała do ważnych elementów ideologii nazistowskiej, a zatem sukces sportowy był szczególnie pożądany przez organizatora powyższej imprezy sportowej, miał bowiem ukazać niemiecką wyższość nad „miękkimi i dekadenckimi” zachodnimi demokracjami (Large, 2007, s. 165). W związku z powyższym hitlerowskie Niemcy włożyły wiele wysiłku w przygotowanie się do igrzysk pod względem sportowym. Drogą do tego miało być omijanie surowych przepisów MKOl dotyczących amatorstwa, a także promowanie sportu masowego. W III Rzeszy funkcjonował bowiem ogólnonarodowy ruch sportowy Siła przez Radość, w którym miliony Niemców uprawiały sport (Walters, 2008 s. 139). Niemcom udało się zrealizować swój zamierzony cel - zwyciężyli w klasyfikacji medalowej, pokonując Stany Zjednoczone. Zdobyli bowiem 33 złote medale, podczas gdy Amerykanie 24 (Miller, 2008, s. 613).

Zupełnie inny poziom rywalizacji o zwycięstwo w klasyfikacji medalowej igrzysk olimpijskich nastał wraz z wybuchem zimnej wojny. W owym czasie stosunki międzynarodowe stały się bipolarne, z silnie zarysowanym konfliktem ideologicznym 
pomiędzy komunistycznym Wschodem i kapitalistycznym Zachodem. W związku z posiadaniem przez obydwa supermocarstwa arsenałów jądrowych i obawy przed wzajemnym unicestwieniem, wojna gorąca nie była pożądana, za wyjątkiem konfliktów peryferyjnych. Wywiązały się w związku z tym alternatywne formy rywalizacji. Pojawił się wyścig zbrojeń, wyścig kosmiczny i w jego ramach wyścig na księżyc czy rywalizacja o wpływy w państwach niezaangażowanych. Rywalizowano także w sporcie, w szczególności we wspomnianej klasyfikacji medalowej igrzysk olimpijskich.

Radziecko-amerykańska rywalizacja w klasyfikacji medalowej igrzysk olimpijskich wywiązała się wraz z dołączeniem ZSRR do ruchu olimpijskiego. Doszło do tego w 1952 r. podczas letnich igrzysk w Helsinkach. Od początku bardzo widoczna była wrogość ZSRR wobec państw zachodnich. Na uwagę zasługuje fakt, iż radzieccy sportowcy nie zamieszkali w wiosce olimpijskiej, gdzie mogli swobodnie kontaktować się z kolegami z innych państw, ale w oddzielnej kwaterze w wiosce Otaniemi, nieopodal radzieckiej bazy morskiej Porkkala, wraz ze sportowcami z innych państw socjalistycznych (Guttmann, 2002, s. 85; Gold, Gold, 2005, s. 180).

Wraz z dołączeniem ZSRR do ruchu olimpijskiego wiadomym było, iż dojdzie do „mieszania” sportu z polityką. Jak wspominał przewodniczący Wszechzwiązkowego Komitetu ds. Kultury Fizycznej i Sportu Nikolaj Romanow, „kiedy zdecydowaliśmy się brać udział w międzynarodowych zawodach, byliśmy zmuszeni do zagwarantowania zwycięstw, inaczej «wolna» burżuazyjna prasa obrzuciłaby błotem cały nasz naród i naszych sportowców... Żeby uzyskać zgodę na wyjazd na międzynarodowe zawody musiałem wysłać specjalną notę do Stalina gwarantując zwycięstwo" (Riordan, 1993, s. 249). Zresztą właśnie obawa przed porażkami była głównym powodem, dla którego ZSRR nie zadebiutował w igrzyskach olimpijskich cztery lata wcześniej w Londynie. Tymczasem Stany Zjednoczone dominowały w igrzyskach olimpijskich od dłuższego czasu. Zaskoczeniem dla całego świata było jednak to, iż Związek Radziecki zgłosił swoich reprezentantów we wszystkich za wyjątkiem hokeja na trawie dyscyplinach rozgrywanych w stolicy Finlandii (Riordan, 1977, s. 367).

Zwycięzcą klasyfikacji medalowej igrzysk olimpijskich w Helsinkach w 1952 roku zostały USA z 40 złotymi medalami, podczas gdy drugi ZSRR zdobył ich 22 (Miller, 2008, s. 612-614). Podział medali wydawał się najrówniejszy w historii, a światowa prasa poświęcała bardzo wiele uwagi ,starciu gigantów”, publikując każdego dnia aktualną tabelę medalową (Guttmann, 1978, s. 98). Sprawa wyników klasyfikacji medalowej letnich igrzysk w Helsinkach nie była jednak tak prosta ze względu na alternatywne metody jej wyliczania. Przykładowo w tzw. metodzie alokacji punktów, zgodnie z którą w każdej rozgrywanej konkurencji przydzielało się punkty za pierwszych 6 miejsc (Riordan, 1978, s. 32), USA i ZSRR zremisowały (Riordan, 1977, s. 367; Shneidman, 1979, s. 25). Mimo to propaganda radziecka informowała o sportowym zwycięstwie ZSRR, chociaż neutralni obserwatorzy poddawali radzieckie wyliczenia w wątpliwość (Tikander, 2004, s. 143; Kultura, s. 10).

Igrzyska olimpijskie w Helsinkach stanowiły dopiero początek całej serii rywalizacji radziecko-amerykańskiej w klasyfikacji medalowej igrzysk olimpijskich. Jak przedstawia poniższa tabela, w czasie trwania zimnej wojny supermocarstwa niemal naprzemiennie w niej zwyciężały. 


\section{Radziecko-amerykańska rywalizacja w klasyfikacjach medalowych letnich igrzysk olimpijskich}

\begin{tabular}{|l|c|c|c|c||}
\hline \hline Igrzyska olimpijskie & Miejsce USA & $\begin{array}{c}\text { Medale zdobyte } \\
\text { przez USA }\end{array}$ & Miejsce ZSRR & $\begin{array}{c}\text { Medale zdobyte } \\
\text { przez ZSRR }\end{array}$ \\
\hline Helsinki 1952 & 1 & $40-19-17$ & 2 & $22-30-19$ \\
\hline Melbourne 1956 & 2 & $32-25-17$ & 1 & $37-29-32$ \\
\hline Rzym 1960 & 2 & $34-21-16$ & 1 & $43-29-31$ \\
\hline Tokio 1964 & 1 & $36-26-28$ & 2 & $30-31-35$ \\
\hline Meksyk 1968 & 1 & $45-28-34$ & 2 & $29-32-30$ \\
\hline Monachium 1972 & 2 & $33-31-30$ & 1 & $50-27-22$ \\
\hline Montreal 1976 & 3 & $34-35-25$ & 1 & $49-41-35$ \\
\hline Moskwa 1980 & 1 & $83-61-30$ & \multicolumn{2}{|c||}{ nie uczestniczy1 } \\
\hline Los Angeles 1984 & 3 & $36-31-27$ & 1 & $55-31-46$ \\
\hline Seul 1988 & 3
\end{tabular}

Źródło: D. Miller, Historia Igrzysk Olimpijskich i MKOl. Od Aten do Pekinu 1894-2008, Poznań 2008, s. 614-617.

Analizując przytoczoną wyżej tabelę należy zwrócić uwagę, iż dwukrotnie USA spadły na trzecie miejsce, przegrywając nie tylko z ZSRR, ale też z Niemiecką Republiką Demokratyczną. To małe państwo satelickie ZSRR musiało walczyć o międzynarodowe uznanie ze względu na to, iż Zachód popierał Republikę Federalną Niemiec, a więc kraj kwestionujący państwowość Niemiec Wschodnich. W konflikcie tym NRD brakowało argumentów, poza protekcją ZSRR. Jej przywódcy zdecydowali się więc wykorzystać sport jako narzędzie zdobywania międzynarodowego zainteresowania, prestiżu oraz docelowo także politycznego uznania. Początkowo NRD nie miała możliwości samodzielnego uczestniczenia w sporcie międzynarodowym. W związku z naciskami ze strony organizacji sportowych powstała zatem wspólna z RFN, ogólnoniemiecka reprezentacja sportowa. Sytuacja taka miała miejsce podczas igrzysk olimpijskich w latach 1956, 1960 i 1964. Dopiero w 1968 roku NRD otrzymała możliwość samodzielnego startu w igrzyskach olimpijskich, natomiast cztery lata później otrzymała możliwość wykorzystywania własnych symboli narodowych - flagi, godła i hymnu. Odkąd Niemcy Wschodnie otrzymały możliwość samodzielnego uczestniczenia w międzynarodowym sporcie, w tym w igrzyskach olimpijskich, kraj ten zadziwiał świat świetnymi wynikami sportowymi. Co ciekawe, wiele z tych zwycięstw związanych było ze stosowaniem niedozwolonych środków dopingujących, chociaż zostało to udowodnione na długo po zakończeniu zimnej wojny (Kuźniak, 2007).

Zakończenie zimnej wojny nie oznaczało wcale końca wykorzystywania tabeli medalowej igrzysk olimpijskich dla politycznych celów. W ostatnim czasie Chiny dążyły do zwycięstwa w klasyfikacji medalowej igrzysk olimpijskich ze względów politycznych. Państwo goszczące letnie igrzyska olimpijskie w 2008 roku nie tylko podjęło próbę zorganizowania najlepszych igrzysk w historii, ale chciało także zwyciężyć pod względem sportowym. Gdy tylko Pekinowi przyznano prawo organizacji tych zawodów sportowych, został wydany szereg aktów rządowych mających na celu zapewnienie zwycięstwa w klasyfikacji medalowej (Houlihan, Green, 2007, s. 46). Najbardziej obiecujący zawodnicy zostali skierowani do specjalnych ośrodków, w których z pomocą naukow- 
ców i trenerów mogli przygotowywać się do olimpijskiego startu (Lewandowski, 2008). Wszystko to funkcjonowało w ramach Systemu Sportu Elitarnego pod nazwą ,Juguo Tizhi”, który został oparty na wzorcach radzieckich (Hong, Wu, Xiong, 2005, s. 510).

Chińczykom udało się zrealizować ten cel, zdobyli bowiem 51 złotych medali. Zgodnie z oczekiwaniami udało się pokonać USA, które z 36 złotymi medalami zajęły drugie miejsce. Co ciekawe, to Amerykanie zdobyli więcej medali łącznie, bowiem 110, podczas gdy Chińczycy 100 (Beijing). Chińczycy jednak w swoich przygotowaniach skupili się na zdobywaniu złotych medali i udało im się ten cel zrealizować, bowiem większość zdobytych przez nich medali było właśnie z najcenniejszego kruszcu. Pojawiły się co prawda oskarżenia o stosowanie nieuczciwych praktyk przez gospodarzy tych igrzysk, nie zostały one jednak potwierdzone.

Na uwagę zasługują także odbywające się w 2014 roku Zimowe Igrzyska Olimpijskie w Sochi w Rosji. W tym przypadku, podobnie jak podczas opisywanych wyżej igrzysk w Pekinie, państwo goszczące zawody zapragnęło wyprawić najlepszą tego typu imprezę w historii, a także zwyciężyć w klasyfikacji medalowej. Chociaż co do jakości najdroższych w historii zimowych igrzysk pojawiały się wątpliwości, mimo że wg wielu ekspertów wydano na nie nawet 51 mld USD (Most, Russia 's), to pod względem sportowym udało się Rosjanom zdominować igrzyska. Zdobyli oni bowiem zarówno najwięcej złotych medali, jak i medali ogółem (Medal).

\section{Prestiżowe zwycięstwa sportowe}

Współzawodnictwu sportowemu może być nadawane polityczne znaczenie nie tylko w kontekście rywalizacji w ilości zdobytych medali podczas wielkich imprez sportowych. Duże znaczenie przywiązywane jest także pojedynczym zwycięstwom sportowym, którym z różnych względów przypisuje się prestiżowe znaczenie. W szczególności dotyczy to sytuacji, kiedy dochodzi do współzawodnictwa pomiędzy państwami, których wzajemne stosunki są nieprzyjazne. Takie pojedynki wzbudzają zawsze szczególne emocje zarówno u kibiców, jak i sportowców, zaś zwycięstwo jest utożsamiane z wygraną całego państwa czy narodu, a czasem także systemu społeczno-politycznego.

Sytuacje związane z nadawaniem politycznego znaczenia konkretnym starciom sportowym były najczęstsze w czasie zimnej wojny, kiedy to z oczywistych względów ilość międzynarodowych antagonizmów była szczególnie duża. Jednak pierwsze tego typu przykłady miały miejsce już przed II wojną światową. Chodzi bowiem o pojedynki bokserskie między Maxem Schmelingiem z Niemiec i Amerykaninem Joe Louisem. Do pierwszej walki między nimi doszło w Nowym Jorku w czerwcu 1936 r., jej zwycięzcą okazał się Niemiec (nokaut w pierwszej rundzie). Za swój sukces Schmeling otrzymał zaproszenie na spotkanie od samego Hitlera. Do rewanżu doszło w 1938 roku. Louis miał ponoć usłyszeć od amerykańskiego prezydenta Franklina Delano Roosevelta „Joe, musimy mieć twoje mięśnie, aby rozbić Niemcy". Amerykanin wygrał, także przez nokaut (Ferenc, 2008, s. 30-31). W sytuacji tej w bardzo wyraźny sposób dostrzec można znaczenie, jakie państwa przykładają do prestiżowych pojedynków sportowych. W walkę bokserską zaangażowali się bowiem przywódcy dwóch mocarstw. 
Jak wspomniano, szczególnie dużo prestiżowych pojedynków sportowych miało miejsce w czasie zimnej wojny, odkąd ZSRR dołączył do międzynarodowej rywalizacji sportowej. Warto wspomnieć o wydarzeniu z igrzysk olimpijskich w Helsinkach w 1952 roku. Chodzi o bieg na $3000 \mathrm{~m}$ z przeszkodami, w którym naprzeciw siebie stanęli radziecki rekordzista świata Władimir Kaznacew oraz dysponujący dużo gorszym rekordem życiowym Amerykanin Horace Ashenfelter. Kaznacew wyprzedził Amerykanina na 200 metrów przed meta, jednak upadł pokonując ostatnią przeszkodę, oddając jednocześnie zwycięstwo Ashenfelterowi, który pobił przy okazji rekord świata (Miller, 2008, s. 159). Emocji całemu wydarzeniu dodawały zawody wykonywane przez obydwu zawodników. Amerykanin był agentem FBI, podczas gdy reprezentant Związku Radzieckiego policjantem, chociaż niektórzy autorzy twierdza, że był urzędnikiem kryminalnym w radzieckim Ministerstwie Spraw Wewnętrznych (Michalik, 1993, s. 480). Sam Ashenfelter jednak niejednokrotnie podkreślał w wywiadach, że dla nich jako sportowców kwestie zimnowojenne nie miały żadnego znaczenia (Robinson, 2008, s. 55). Niemniej jednak, amerykańska prasa w bardzo emocjonalny sposób opisywała to wydarzenie jako ważny element konfrontacji Wschodu z Zachodem (Tikander, 2004, s. 143). Pojawiały się także pisane nieco z przekąsem opinie, odnoszące się do profesji Amerykanina, że „nigdy wcześnie człowiek z FBI nie pozwolił Rosjaninowi podazżać za nim tak blisko" (Hornbuckle, 1996, s. 115).

Szczególnie istotne pod względem prestiżowym wydają się zmagania w sportach zespołowych. W okresie zimnej wojny na szczególną uwagę zasługują olimpijskie pojedynki koszykarskie pomiędzy USA a ZSRR. Do meczów finałowych w koszykówce mężczyzn podczas igrzysk olimpijskich z udziałem tych krajów doszło wielokrotnie, w latach 1952, 1956, 1960, 1964 i 1972 (Miller, 2008, s. 517). Za najistotniejszy z punktu widzenia znaczenia politycznego można jednak uznać ten z Monachium, z roku 1972. Mecz wzbudzał tak wielkie zainteresowanie, że w hali zmieściło się tylko $10 \%$ zainteresowanych obejrzeniem go na żywo (Roman, 1973, s. 16). Po serii bardzo kontrowersyjnych decyzji sędziowskich zwycięstwo przyznano Związkowi Radzieckiemu (Finley, Finley, Fountain, 2008, s. 132; Allen, 2010, s. 138-140; Miller, 2008, s. 132; Huberty, Wange, 1972, s. 192). Amerykanie złożyli oficjalny protest, oświadczając, iż interesuje ich ,złoto lub nic”. Był on rozpatrywany przez pięcioosobową komisję FIBA, w której zasiadali obywatele Polski, Węgier, Kuby, Włoch i Puerto Rico. Po 14 godzinach obrad doszło do tajnego głosowania, w którym wynikiem 3-2 zwycięstwo przyznano ZSRR (Stradling, 2009, s. 138-139). Była to zarazem pierwsza porażka Amerykanów w ogóle w historii koszykówki na igrzyskach olimpijskich.

Innym godnym uwagi prestiżowym starciem pomiędzy ZSRR a USA w sportach zespołowych był mecz hokejowy z igrzysk olimpijskich w Lake Placid w 1980 roku, określany przez Amerykanów jako „cud na lodzie”, bowiem amatorska reprezentacja tego kraju wygrała 4-3, mimo że ZSRR był uważany za najlepszą drużynę hokejową świata, która od 1963 roku wygrała 14 z 17 rozgrywanych corocznie mistrzostw świata oraz 4 wcześniejsze zimowe igrzyska olimpijskie (Miller, 2008, s. 599). Mecz ten miał także znaczenie z powodu kontekstu polityki międzynarodowej. Na krótko przed igrzyskami w Lake Placid Związek Radziecki dokonał interwencji zbrojnej w Afganistanie, czym spowodował silne antyradzieckie reakcje w społeczeństwach zachodnich oraz zakończył okres odprężenia w stosunkach Wschód-Zachód. Zatem już przed meczem, mimo niewielkich szans na zwycięstwo, prasa amerykańska wyrażała głębokie nadzieje 
na pokonanie ZSRR, natomiast kiedy do tego doszło, było ono określane jako symbol zwycięstwa USA w zimnej wojnie. Prezydent USA Jimmy Carter określił amerykańską drużynę hokejową jako „współczesnych amerykańskich bohaterów” (Billings, Butterworth, Turman, 2012, s. 137; Hill, 1996, s. 126).

Nadawanie politycznego znaczenia poszczególnym starciom sportowym było w okresie zimnej wojny typowe dla rywalizacji Wschodu z Zachodem, jednak pojawiały się także nieco inne przykłady - dotyczące rywalizacji państw należących do tego samego bloku geopolitycznego. Wspomnieć w tym miejscu można o meczu Węgry-ZSRR w piłkę wodną podczas igrzysk olimpijskich w Melbourne w 1956 roku, odbywającym się z interwencją radziecką na Węgrzech w tle. Wspomniany mecz piłki wodnej był pełen przemocy i bójek (Espy, 1981, s. 55). Momentem kulminacyjnym było uderzenie głową przez Walentina Prokopowa Węgra Erwina Zadora i rozcięcie mu łuku brwiowego (Miller, 2008, s. 175). Wówczas w wodzie pojawiła się krew, co doprowadziło do wściekłości kibicujących Węgrom australijskich kibiców. Zawodnicy radzieccy ledwo uniknęli zlinczowania przez widzów meczu, a przy krawędzi basenu stanęli węgierscy działacze i rezerwowi i zaczęli krzyczeć wyzwiska w stronę zawodników radzieckich (Grzegrzółka, 2008, s. 23; Rinehart, 1996, s. 131). Podobny charakter miały mecze hokejowe pomiędzy ZSRR a Czechosłowacją podczas mistrzostw świata w Sztokholmie w 1969 r., które były pokłosiem interwencji wojsk Układu Warszawskiego w Czechosłowacji w sierpniu 1968 roku. Podczas wspomnianych mistrzostw doszło do dwóch meczów pomiędzy drużynami ZSRR a CSRS, wygranymi przez Czechosłowację. Charakterystycznym było, że w ich trakcie zawodnicy Czechosłowaccy odmówili podania rąk przeciwnikom. Jak mówili, ,przybyliśmy tu po to, aby pokonać Rosjan” (Michalik, 1993, s. 629). W następstwie drugiego z meczy doszło nawet do zamieszek w Pradze. Zaatakowano m.in. sowieckie koszary, a także splądrowano biuro radzieckich linii lotniczych Aeroflot (Soares, 2007, s. 212). Był to zatem przykład sytuacji, w której wydarzenie sportowe w pewnym sensie sprowokowało wydarzenia polityczne.

Po zakończeniu zimnej wojny prestiżowe, silnie upolitycznione pojedynki sportowe stały się rzadsze i nabrały bardziej łagodnego wymiaru. Wciąż jednak do nich dochodzi i są one na ogół powiązane z konkretnymi wydarzeniami politycznymi. Przykładowo igrzyska olimpijskie w Pekinie rozpoczęły się tego samego dnia co wojna pomiędzy Rosją i Gruzją. Oczekiwano zatem, iż jeśli dojdzie w ich trakcie do pojedynków rosyjskogruzińskich, zawodnicy mogą wyrazić wzajemną wrogość, mimo że Międzynarodowy Komitet Olimpijski zdecydowanie zabrania tego typu działań. Wbrew oczekiwaniom mediów nie doszło jednak do takich sytuacji. Na uwagę zasługuje tymczasem mecz mistrzostw świata w piłce nożnej w 1998 r. pomiędzy USA i Iranem. W jego trakcie napięcie było bardzo widoczne, chociażby w odniesieniu do takich elementów sportowego widowiska jak uściski dłoni. Irański przywódca Ali Khamenei nakazał bowiem piłkarzom nie podchodzić do Amerykanów w celu uściśnięcia dłoni przed meczem, mimo że zgodnie z przepisami Międzynarodowej Federacji Piłkarskiej FIFA byli do tego zobowiązani (jako drużyna B, podczas gdy Amerykanie przystępowali do tego meczu jako drużyna A). Obecnym na stadionie kibicom irańskim udało się ponadto utworzyć na trybunach wielką szarfę, jednak kamery telewizyjne nie pokazały jej (Billingham, 2014). Sam mecz miał jednak spokojny przebieg i zakończył się zwycięstwem Iranu 2-1. Obecnie jednak takie pojedynki należą do rzadkości. 


\section{Organizacja imprez sportowych}

Do sprzężeń pomiędzy sportem a polityką może dochodzić nie tylko w związku ze współzawodnictwem sportowym. Rywalizacja polityczna państw może bowiem uobecniać się $\mathrm{w}$ świecie sportu także w związku $\mathrm{z}$ organizowaniem imprez sportowych, co w szczególności dotyczy tych najważniejszych i najpopularniejszych, takich jak igrzyska olimpijskie oraz mistrzostwa Świata i Europy piłce nożnej. Wymagają one ogromnych nakładów inwestycyjnych, z którymi nie każdy kraj jest w stanie sobie poradzić. Gospodarz takiej imprezy sportowej może jednak czerpać z niej szereg korzyści, w szczególności ekonomicznych, marketingowych i politycznych. Zyski finansowe $\mathrm{z}$ takiego przedsięwzięcia mogą pochodzić ze sprzedaży praw telewizyjnych, biletów czy też od sponsorów. Poprzez organizację imprez sportowych gospodarz może także promować się pod względem turystycznym, a także budować pozytywny wizerunek kraju czy miasta, co może zachęcać zagraniczne firmy do inwestowania. Ponadto, wskazać można także na polityczne przyczyny organizacji imprez sportowych. Niekiedy gospodarz decyduje się na podjęcie próby zorganizowania najlepszej imprezy sportowej danego typu w historii, co świadczyć ma o jego potędze. Podobnie jak w walce o sukcesy sportowe z politycznych względów, także w tym przypadku można dostrzec, iż państwa niedemokratyczne szczególnie często wydają się dążyć do wykorzystania organizacji imprez sportowych dla budowy prestiżu, chcąc demonstrować swoją siłę, zarówno w kontekście wewnętrznym, jak i międzynarodowym.

Pierwszym tego typu przykładem były wspominane już igrzyska olimpijskie w Berlinie w 1936 roku, organizowane przez nazistowską III Rzeszę. Niemcy postanowili zadziwić świat przede wszystkim poprzez infrastrukturę oraz architekturę. Stadion olimpijski, który został wybudowany z myślą o igrzyskach w 1916 roku, które się jednak nie odbyły z uwagi na I wojnę światowa, został całkowicie przebudowany. Wrażenie robiły również pływalnia oraz wioska olimpijska. System transportu sportowców określany był jako doskonały, a także wprowadzono swego rodzaju nowinki technologiczne, takie jak fotokomórka oraz transmisje telewizyjne (Miller, 2008, s. 125). Niemcy i Berlin miały być ponadto pokazane jako miejsce pokoju i szczęścia, a samo miasto goszczące igrzyska zostało udekorowane flagami olimpijskimi i nazistowskimi. Berlińczykom nakazano natomiast uśmiechać się i być miłym dla odwiedzających. Plan ten okazał się skuteczny, bowiem zachodnia prasa chwaliła Niemcy jako kraj szczęśliwy i bogaty, zaś Hitlera opisywano jako ,jednego z największych żyjących przywódców politycznych" (Walters, 2008, s. 269, 333).

Wiele podobieństw do opisanych powyżej igrzysk w Berlinie można zaobserwować w bardziej współczesnych igrzyskach olimpijskich - w Moskwie w 1980 r., jeszcze w okresie zimnej wojny, oraz w Pekinie w 2008 roku, a także w Sochi w 2014 roku. Imprezy te były organizowane w państwach niedemokratycznych i miały w założeniach być najlepszymi igrzyskami w historii. Zarówno w ZSRR, w ChRL jak i w Rosji zdecydowano się ponadto na wyeksponowanie obiektów sportowych jako elementów przemawiających za szczególnością tych imprez sportowych. W związku z igrzyskami w Moskwie odremontowano stadion im. Lenina, a także zbudowano Pałac Sportu (Miller, 2008, s. 259). Z kolei Chińczycy byli szczególnie dumni ze stadionu olimpijskiego nazywanego „Ptasim Gniazdem” oraz pływalni, określanej jako „Wodna Kostka”. 
W Sochi obiekty nie wyróżniały się w aż takim stopniu, były jednak chwalone za przez sportowców (Williams, 2014). Wiele uwagi przywiązywali organizatorzy tych zawodów także do ceremonii otwarcia, które wydają się być świetnym sposobem na „przesyłanie wiadomości światu”, ze względu na powszechne zainteresowanie, jakie przykuwają. Chińczycy np. podczas ceremonii otwarcia igrzysk w Pekinie postanowili wyeksponować elementy cywilizacji chińskiej, ale także ukazać Chiny jako państwo nastawione pokojowo, jak zinterpretowano to na łamach „New York Timesa” (Yardley, 2008). Także w Sochi starano się eksponować lokalną kulturę i dziedzictwo, jednak wg obserwatorów nie udało się przyćmić pod tym względem wcześniejszych igrzysk (Dewey, 2014).

Przykładów wysyłania przez państwa komunikatów podczas organizacji zawodów sportowych jest oczywiście znacznie więcej. Na uwagę zasługują chociażby mistrzostwa świata w piłce nożnej, organizowane przez Republikę Południowej Afryki w 2010 roku. Był to pierwszy raz, kiedy wspomniana impreza sportowa odbywała się w Afryce. W związku z tym, organizatorzy starali się eksponować afrykańskie symbole. Jak stwierdził prezydent RPA Thabo Mbeki, celem organizacji mistrzostw było sprawienie, aby ludzie od Kapsztadu po Kair stali się bardziej pewni siebie i aby w przyszłości historycy ocenili te mistrzostwa jako moment, w którym Afryka porzuciła ostatecznie okres biedy i konfliktów (Runciman, 2010). Chociaż trudno jest na tym etapie stwierdzić, czy plan ten się powiódł, z całą pewnością można powiedzieć, iż organizacja drugiej największej imprezy sportowej świata poza letnimi igrzyskami olimpijskimi zakończyła się sukcesem, chociaż przed mistrzostwami wyrażano obawy związane z dużą przestępczością, jaka panuje w RPA.

\section{Udział w międzynarodowej rywalizacji sportowej}

W powyższych fragmentach przedstawione zostało nadawanie politycznego znaczenia sportowi w związku ze współzawodnictwem sportowym oraz chęcią zorganizowania jak najlepszych zawodów sportowych. Okazuje się jednak, iż sport może mieć znaczenie polityczne także jeśli weźmie się pod uwagę uczestnictwo w nim. Dzieje się tak w sytuacji, w której dane państwo dopiero konsoliduje swoją państwowość, a co za tym idzie, potrzebuje uznania międzynarodowego jako jednego z podstawowych atrybutów państwa. Często przychodzi ono naturalnie wraz z ukonstytuowaniem się władzy na danym terytorium. Czasami jednak istnienie danego państwa jest kwestionowane i musi ono zabiegać o uznanie międzynarodowe. Udział w międzynarodowej rywalizacji sportowej wydaje się zatem istotnym elementem drogi do powszechnego uznania dla danego państwa. Skoro zostało ono uznane przez międzynarodową organizację sportową, to w pewnym ograniczonym sensie oznacza to akceptację dla jego istnienia - może ono wówczas rywalizować z kontestującymi jego podmiotowość krajami. Państwa nieposiadające powszechnego uznania bardzo silnie zabiegają więc o możliwość brania udziału w międzynarodowych imprezach sportowych. Nie zawsze udaje im się zdobywać medale, jednak istotna dla nich może być chociażby obecność podczas ceremonii otwarcia i zamknięcia danej imprezy sportowej, „ramię w ramię" z pełnoprawnymi i powszechnie uznawanymi państwami.

Takie wykorzystanie sportu w historii często wiązało się z rywalizacją podzielonych państw w związku z ich ambicją bycia jedynym przedstawicielem danego narodu czy 
terytorium. Dotyczyło w szczególności dwóch przypadków, opisywanych jako sprawy chińska i niemiecka w międzynarodowym sporcie. Sprawa niemiecka była już wspomniana wcześniej przy okazji opisywania świetnych osiagnięć sportowych Niemieckiej Republiki Demokratycznej. Tzw. sprawa chińska w międzynarodowym sporcie była podobna. W wyniku wojny domowej powstały dwa państwa chińskie: Republika Chińska na Tajwanie oraz komunistyczna Chińska Republika Ludowa. Republika Chińska utrzymała uznanie państw zachodnich, podczas gdy państwa komunistyczne nawiązały stosunki z ChRL. Przedstawiciele obydwu państw byli zainteresowani udziałem w igrzyskach olimpijskich w Helsinkach w 1952 roku, stawiając MKOl w trudnej sytuacji. Sytuację komplikowało dodatkowo wzajemne nieakceptowanie się obu państw. Ostatecznie zdecydowano jednak, iż Komitet nie uzna na razie żadnego z państw chińskich, jednak wszyscy chińscy sportowcy, którzy przyjadą do Helsinek, będą mogli wziąć udział w igrzyskach (Hill, 1996, s. 44-45). W reakcji na tę decyzję z udziału w nich zrezygnował Tajwan (Tikander, 2004, s. 142). Cztery lata później także obydwa państwa chińskie zostały dopuszczone do udziału w igrzyskach, jednak wówczas to komunistyczne Chiny zdecydowały się zbojkotować te zawody na wieść o tym, iż w wiosce olimpijskiej zakwaterowali się sportowcy reprezentujący Republikę Chińską (Guoqi, 2008, s. 85).

Obydwa kraje domagały się wykluczenia ideologicznego wroga z ruchu olimpijskiego, a kiedy to się nie udało, komunistyczne Chiny w 1958 roku zerwały wszelkie kontakty zarówno z MKOl-em, jak i ze światowym sportem w ogóle (Guoqi, 2008, s. 85-86). Chińska Republika Ludowa pozostawała w sportowej izolacji aż do początku lat siedemdziesiątych, kiedy to doszło do ponownego otwarcia, przy wykorzystaniu tzw. dyplomacji pingpongowej. ChRL zaczęła wówczas wstępować do kolejnych federacji sportowych, co często wiązało się z wykluczeniem z nich Tajwanu. Na drodze do przystąpienia do MKOl stał jednak fakt, iż Komitet nie chciał wykluczyć mniejszego z państw chińskich. Do rozstrzygnięcia doszło dopiero pod koniec lat siedemdziesiątych. W 1979 roku przedstawiciele ChRL wyrazili zgodę na jednoczesne należenie do MKOl zarówno Tajwanu, jak i Chin komunistycznych. Przywódcy Republiki Chińskiej, chociaż nie od razu, zaakceptowali takie rozstrzygnięcie.

\section{Bojkot sportowy}

Obok opisanego wyżej uczestnictwa w międzynarodowym sporcie, polityczne znaczenie może mieć także sytuacja odwrotna, a więc jego brak. Chodzi mianowicie o bojkot sportowy, a zatem jeden z najbardziej jaskrawych przejawów przenoszenie na grunt sportu politycznej rywalizacji państw. Współcześnie do bojkotów sportowych w klasycznej formie właściwie nie dochodzi, jednakże w niedalekiej przeszłości była to broń bardzo chętnie wykorzystywana przez szereg państw. Bojkot sportowy jako broń polityczną szczególnie upodobały sobie państwa afrykańskie. Mogły one bowiem wykorzystywać go do oddziaływania na społeczność międzynarodową, w celu realizacji swoich politycznych interesów.

Państwa afrykańskie stosowały groźbę bojkotu różnych imprez sportowych, w szczególności igrzysk olimpijskich, przede wszystkim mając na celu upublicznienie zagadnienia istnienia rasistowskich reżimów w Afryce - w RPA i Rodezji. W tym celu utworzy- 
ły Najwyższą Radę Sportu w Afryce (SCSA), która koordynowała ich działania (Bass, 2002, s. 140). Państwa afrykańskie po raz pierwszy zagroziły bojkotem odbywających się w 1968 r. igrzysk olimpijskich w Meksyku, doprowadzając do wykluczenia z nich Republiki Południowej Afryki (Macintosh, Hawes, 1994, s. 67). Podobna sytuacja miała miejsce cztery lata później w związku z igrzyskami w Monachium, jednak tym razem groźba bojkotu, jaka w ostatniej chwili pojawiła się ze strony państw afrykańskich, dotyczyła udziału sportowców reprezentujących Rodezję, kolejnego kraju afrykańskiego zdominowanego przez białą mniejszość, w którym sportowcy czarnoskórzy nie byli jednak dyskryminowani. Także w tym przypadku ich działania okazały się skuteczne i pomimo wcześniejszych porozumień wykluczono z igrzysk Rodezję (Espy, 1981, s. 129; Miller, 2008, s. 223-224; Guttmann, 2002, s. 135). Do trzeciej z kolei groźby bojkotu igrzysk olimpijskich ze strony państw afrykańskich doszło podczas kolejnej tego typu imprezy - w Montrealu w 1976 roku. Tym razem skupione w Najwyższej Radzie Sportu w Afryce państwa zaprotestowały przeciwko tournee, jakie reprezentacja Nowej Zelandii w rugby odbyła po Republice Południowej Afryki w 1976 roku. Kraje afrykańskie domagały się usunięcia Nowej Zelandii z igrzysk lub chociaż potępienia wspomnianego tournee przez MKOl i Narodowy Komitet Olimpijski Nowej Zelandii. Przedstawiciele obydwu organizacji odmówili jednak, stwierdzając, iż rugby nie jest sportem olimpijskim i nie mają nad nim jurysdykcji (Mason, 2007, s. 291). Nie ugięto się zatem ponownie pod żądaniem ze strony państw afrykańskich, te zaś, nie chcąc utracić honoru w związku z brakiem uzyskania jakichkolwiek ustępstw, zdecydowały się zbojkotować igrzyska w Montrealu. Doszło więc do pierwszego masowego bojkotu imprezy sportowej z przyczyn politycznych.

Zupełnie osobną kwestią odnośnie bojkotów sportowych były te dotyczące igrzysk olimpijskich w Moskwie w 1980 roku oraz w Los Angeles w 1984 roku. Bojkoty te miały charakter typowo zimnowojenny i jak się wydaje, miały na celu uderzenie w ideologicznego rywala poprzez zdeprecjonowanie znaczenia organizowanych przez niego letnich igrzysk olimpijskich. Igrzyska w Moskwie zostały zbojkotowane przez USA oraz część ich sojuszników. Oficjalnym powodem była radziecka interwencja w Afganistanie, do jakiej doszło pod koniec 1979 roku (Caraccioli, Caraccioli, 2008, s. 59). Nie udało się to jednak w pełni, ponieważ wiele z Narodowych Komitetów Olimpijskich w państwach sojuszniczych USA cieszyło się niezależnością i wbrew naciskom ze strony rządów decydowało się wysłać sportowców do Moskwy. Tak było chociażby w przypadku Wielkiej Brytanii (Espy, 1981, s. 194-195). Niemniej bojkot igrzysk w Moskwie był największy w historii, bowiem wzięło w nim udział aż 67 państw (Moscow).

Bojkot igrzysk w Los Angeles przez państwa komunistyczne powszechnie uważany jest za rewanż za bojkot odbywających się cztery lata wcześniej igrzysk w Moskwie. Prawdopodobnie było tak w rzeczywistości, jednak przez właściwie cały okres olimpiady poprzedzającej igrzyska w Los Angeles wiele wskazywało, że państwa komunistyczne jednak wezmą w nich udział. Sytuacja zmieniła się dopiero w lutym 1984 roku, wraz ze zmianą kierownictwa w ZSRR. Zmarłego Jurija Andropowa zastapił Konstantin Czernienko (Reich, 1984, s. 19). Właśnie wówczas zaczęła się zarysowywać groźba odwetowego bojkotu ze strony państw komunistycznych (Miller, 2008, s. 275), do którego ostatecznie doszło. Jako powód strona radziecka podała niebezpieczeństwo związane z funkcjonowaniem w USA ekstremistycznych grup antyradzieckich (Guttmann, 2002, 
s. 157). Z bloku radzieckiego wyłamała się jedynie Rumunia, która wysłała swoją reprezentację do Los Angeles (Wilson, 2004, s. 212).

Powyższe wybrane przykłady sportowych bojkotów, bądź ich gróźb, w sposób bardzo wyraźny pokazują, iż sport może w bardzo bezpośredni sposób być wykorzystywany w świecie polityki, jako swoista broń mogąca w sposób skuteczny i stosunkowo tani uderzać w politycznych przeciwników. Pozwolił on państwom afrykańskim doprowadzić do izolacji pod względem sportowym kontestowanych przez siebie państw - RPA i Rodezji, zaś zimnowojenne supermocarstwa wykorzystały go jako możliwość bezpośredniego uderzenia w ideologicznego rywala. Obecnie jednak bojkoty sportowe są już dużo mniej chętnie stosowane, co najwyżej politycy rezygnują z uczestniczenia w ceremoniach otwarcia i zamknięcia imprez sportowych, co normalnie chętnie czynią. Dzieje się tak, ponieważ najbardziej bezpośrednimi ofiarami bojkotów sportowych są sportowcy reprezentujący kraje, które rezygnują z udziału w danych zawodach sportowych. Tymczasem najczęściej znacznie mniej traci na sportowym bojkocie podmiot, przeciwko któremu jest on w rzeczywistości skierowany. Stosunkowo skuteczne okazały się jedynie groźby bojkotów stosowane przez państwa afrykańskie.

\section{Konkluzje}

Badania, których wyniki zostały przedstawione w niniejszym artykule, pozwoliły na wskazanie pięciu najbardziej charakterystycznych przejawów sprzężeń pomiędzy sportem a polityką, związanych z międzynarodową rywalizacją pomiędzy państwami. Dwa pierwsze związane były $z$ nadawaniem politycznego znaczenia rywalizacji sportowej - w kontekście uzyskiwania przez państwa jak najwyższego poziomu sportowego, którego wyrazem jest duża ilość medali zdobytych podczas igrzysk olimpijskich, a także w kontekście nadawania politycznego znaczenia traktowanym jako prestiżowe konkretnym starciom sportowców. Było to związane z kwestiami wizerunkowymi i chęcią podkreślania na forum międzynarodowym potęgi danego państwa.

Organizacja imprez sportowych w kontekście rywalizacji politycznej państw także wiąże się ze współzawodnictwem, jednak tym razem w kontekście organizacyjnym. Celem jest w tym przypadku urządzenie jak najlepszej imprezy sportowej i, co za tym idzie, nadanie komunikatu o wielkim potencjale organizatora danego wydarzenia sportowego.

Ostatnie dwa poddane analizie zagadnienia dotyczą uczestnictwa w międzynarodowym sporcie bądź też rezygnacji z niego, co określane jest jako bojkot sportowy. W przypadku państw o niejednoznacznym statusie udział w międzynarodowych zawodach sportowych służy jako potwierdzenie ich podmiotowości, natomiast bojkot oraz jego groźba stanowią polityczną broń mającą na celu uderzenie w dany podmiot, najczęściej państwo goszczące daną imprezę sportową bądź organizację sportową.

Poszczególne studia przypadków pozwoliły na zaobserwowanie szeregu prawidłowości. Jeżeli chodzi o cele nadawania politycznego znaczenia międzynarodowej rywalizacji sportowej, to należą do nich w szczególności chęć podniesienia własnego prestiżu oraz chęć uderzenia w innych aktorów stosunków międzynarodowych, w szczególności państwa. Do podniesienia prestiżu państwa przy wykorzystaniu sportu może dochodzić w sytuacjach, kiedy jego reprezentacja uzyskuje sukcesy w międzynarodowej rywaliza- 
cji, zarówno jeżeli chodzi o liczbę zdobywanych medali, jak również w związku z prestiżowymi zwycięstwami. Podobny cel może mieć organizacja międzynarodowych imprez sportowych. Zagadnienie to bywa także analizowane z perspektywy kształtowania wizerunku zewnętrznego państwa, jednak w kontekście niniejszego badania szczególna uwaga położona była na kontekst rywalizacji między zwaśnionymi państwami. Z kolei drugi cel - chęć uderzenia w innych aktorów stosunków międzynarodowych, związany jest przede wszystkim z wykorzystywaniem sportu jako swoistej broni politycznej. Poprzez sportowy bojkot państwo może uderzyć organizatora zawodów sportowych bądź organizację sportowa, natomiast $\mathrm{w}$ przypadku istnienia państw podzielonych popieranie uczestnictwa jednego $\mathrm{z}$ nich $\mathrm{w}$ międzynarodowym sporcie jest tożsame $\mathrm{z}$ uderzaniem $\mathrm{w}$ drugie.

Zauważono także, iż szczególnie często do nadawania rywalizacji sportowej politycznego znaczenia dochodzi w związku z zaistnieniem konfliktów międzynarodowych, a także kiedy stroną takiej konfrontacji jest państwo niedemokratyczne. Stwierdzić trzeba także, iż o ile sprzężenia pomiędzy światem sportu i polityki związane są z wpływaniem kwestii politycznych na sport, to niekiedy relacja ta przyjmuje charakter odwrotny i to wydarzenia sportowe w pewnym sensie prowokują zaistnienie wydarzeń politycznych.

\section{Bibliografia}

Allen G. (2010), What Washington Can Learn from the World of Sports, Regnery Publishing, Washington.

Bass A. (2002), Not the Triumph but the Struggle. The 1968 Olympics and the Making of the Black Athlete, University Of Minnesota Press, Minneapolis.

Beijing 2008 Medal Table, BBC, 13.08.2012, http://www.bbc.co.uk/sport/olympics/2012/medals/historical-medals-beijing-2008/countries, 19.03.2016.

Bian X. (2005), Predicting Olympic Medal Counts: the Effects of Economic Development on Olympic Performance, „The Park Place Economist”, vol. XIII, nr 37-38.

Billingham N., 98: The most politically charged game in World Cup history, FourFourTwo, 6.06.2014, http://www.fourfourtwo.com/features/98-most-politically-charged-game-world-cup-history\#X4Hgu7CXPiXYus4j.99, 19.03.2016.

Billings A. C., Butterworth M. L., Turman P. D. (2012), Communication and Sport. Surveying the Field, SAGE, London.

Bloyce D., Smith A. (2010), Sport Policy and Development. An Introduction, Routledge, Abingdon.

Caraccioli T., Caraccioli J. (2008), Boycott. Stolen Dreams of the 1980 Moscow Olympic Games, New Chapter Press, Washington D.C.

Dewey C., Journalists at Sochi are live-tweeting their hilarious and gross hotel experiences, 4.02.2014, http://www.washingtonpost.com/blogs/worldviews/wp/2014/02/04/journalists-at-sochi-are-live-tweeting-their-hilarious-and-gross-hotel-experiences/, 14.05.2014.

Espy R. (1981), The Politics of the Olympic Games. With Epilogue, 1976-1980, University of California Press, Berkeley-Los Angeles-London.

Ferenc J. (2008), Sport w stużbie polityki. Wyścig Pokoju 1948-1989, Trio, Warszawa.

Finley P., Finley L., Fountain J. (2008), Sports Scandals, Greenwood, Westport.

Gold J. R., Gold M. M. (2005), Cities of Culture. Staging International Festivals and the Urban Agenda, 1851-2000, Routledge, Hants-Burlington.

Grzegrzółka K. (2008), Sportowa wojna światowa, „Wprost”, nr 35.

Guoqi X. (2008), Olympic Dreams. China and Sports 1895-2008, Harvard University Press, Cambridge. 
Guttmann A. (1978), From Ritual to Record. The Nature of Modern Sports, Columbia University Press, New York.

Guttmann A. (2002), The Olympics. A History of Modern Games, University of Illinois Press, Champaign.

Hill C. R. (1996), Olympic Politics. Athens to Atlanta 1896-1996, Manchester University Press, Manchester-New York.

Holt R. (1992), Sport and the British. A Modern History, Oxford University Press, Oxford.

Hong F., Wu P., Xiong H. (2005), Beijing Ambitions: An Analysis of the Chinese Elite Sports System and its Olympic Strategy for the 2008 Olympic Games, ,The International Journal of the History of Sport", vol. 22, Issue 4.

Hornbuckle A. R. (1996), Helsinki 1952, w: Historical Dictionary of the Modern Olympic Movement, red. J. E. Findling, K. D. Pelle, Greenwood, Westport-London.

Houlihan B., Green M. (2007), Comparative Elite Sport Development, Routledge, Oxford-Burlington.

Hoye R., Nicholson M., Houlihan B. (2010), Sport and Policy. Issues and Analysis, Elsevier Butterworth-Heinemann, Oxford-Burlington.

Huberty E., Wange W. B. (1972), Die Olympischen Spiele. München, Aubsburg, Kiel, Sapporo, Lingen Verlag, Köln.

Kultura Fizyczna i Sport w Zwiqzku Radzieckim. Materiaty do pogadanki na Miesiac Pogłęienia Przyjaźni Polsko-Radzieckiej (1953), Biuro Propagandy i Agitacji GKKF, Warszawa.

Kuźniak A. (2007), Zabijali we mnie Heidi, „Duży Format, Dodatek do Gazety Wyborczej”, nr 304 31.12.2007-01.01.2008.

Large D. C. (2007), Nazi Games. The Olympics of 1936, W. W. Norton \& Company, New York-London.

Lewandowski R. (2008), Sportowe i polityczne przygotowania Chińskiej Republiki Ludowej do Igrzysk Olimpijskich Pekin 2008, http://www.polska-azja.pl/2008/08/09/rafal-lewandowskisportowe-i-polityczne-przygotowania-chinskiej-republiki-ludowej-do-igrzysk-olimpijskichpekin-2008/, 17.01.2009.

London 2012 opening ceremony audience hit 900 million predicts IOC (2012), 7.08.2012, „Independent", http://www.independent.co.uk/sport/olympics/news/london-2012-opening-ceremonyaudience-hit-900-million-predicts-ioc-8015361.html, 19.03.2016.

Macintosh D., Hawes M. (1994), Sport and Canadian Diplomacy, McGill - Queens's University Press, Montreal-Buffalo-London.

Mason C. W. (2007), The Bridge to Change: The 1976 Montreal Olympic Games, South African Aparthed Policy, and the Olympic Boycott Paradigm, w: Onward to the Olympics. Historical Perspectives on the Olympic Games, red. G. P. Schaus, S. R. Wenn, Wilfrid Laurier University Press, Waterloo.

Medal Table (2014), BBC, 23.02.2014, http://www.bbc.com/sport/winter-olympics/2014/medals/countries, 19.03.2016.

Michalik M. B. (red.) (1993), Kronika Sportu, Wydawnictwo Kronika, Warszawa.

Miller D. (2008), Historia igrzysk olimpijskich i MKOl. Od Aten do Pekinu 1894-2008, Rebis, Poznań.

Młodzikowski G. (1981), Uniwersalne wartości sportu, w: Sport i kultura, red. Z. Krawczyk, PWN, Warszawa.

Moscow 1980, IOC, http://www.olympic.org/moscow-1980-summer-olympics, 19.03.2016.

Most expensive Olympics in history: Sochi 2014 Games to cost over $\$ 50$ billion, „Russia Today”, 4.02.2014, http://rt.com/business/sochi-cost-record-history-404/, 9.05.2014.

Reich K. (1984), Doleful Days for the Games, „Sports Illustrated”, vol. 60, Issue 20.

Rinehart R. E. (1996), ,,Fists flew and blood flowed”: Symbolic Resistance and International Response in Hungarian Water Polo at Melbourne Olympics, 1956, ,Journal of Sport History”, vol. 23, nr 2.

Riordan J. (1977), Sport in Soviet Society, Cambridge University Press, Cambridge. 
Riordan J. (1978), The U.S.S.R., w: Sport under communism. The U.S.S.R., Czechoslovakia, The G.D.R., China, Cuba, red. J. Riordan, C Hurst \& Co Publishers Ltd, Montreal.

Riordan J. (1993), Rewriting Soviet Sports History, „Journal of Sport History”, vol. 20, nr 3.

Robinson R. (2008), 800m \& 3000m Steeplechase, „Running Times”, Issue 356.

Roman A. (1973), Monachijskie sensacje, Wydawnictwo „Sport i Turystyka”, Warszawa.

Runciman D. (2010), Powitanie z Afrykq, „Tygodnik Forum”, nr 23, http://www.tygodnikforum.pl/ forum/index.jsp?place $=$ Lead10\&news_cat_id $=249 \&$ news_id $=8858 \&$ layout $=1 \&$ forum_ $\mathrm{id}=6861 \&$ page $=$ text, 16.10 .2012 .

Russia's \$9.4B road to Sochi latest in long line of Olympic boondoggles, Fox News, 7.02.2014, http://www.foxnews.com/sports/2014/02/07/sochi-olympic-price-tag-soars-critic-slams-roadthat-could-have-been-paved-with/, 9.05.2014.

Shneidman N. N. (1979), The Soviet road to olympus. Theory and practice of soviet physical culture and sport, Routledge, London.

Soares J. (2007), Cold War, Hot Ice: International Ice Hockey 1947-1980, „Journal of Sport History”, vol. $34, \mathrm{nr} 2$.

Stradling J. (2009), More than a Game. When history and sport collide, Pier 9.

Tikander V. (2004), Helsinki 1952, w: Encyclopedia of the Modern Olympic Movement, red. J. E. Findling, K. D. Pelle, Greenwood, Westport.

TVP podała wyniki: rekord ogladalności pobity! (2012), 9.06.2012, Polski Radio, http://www.polskieradio.pl/5/3/Artykul/621527,TVP-podala-wyniki-rekord-ogladalnosci-pobity, 19.03.2016.

Walters G. (2008), Igrzyska w Berlinie. Jak Hitler ukradt olimpijski sen, Rebis, Poznań.

Williams O., Sochi 2014: First British arrivals impressed by venues, 1.02.2014, http://www.bbc.com/ sport/0/winter-olympics/25996333, 19.03.2016.

Wilson W. (2004), Los Angeles 1984, w: Encyclopedia of the Modern Olympic Movement, red. J. E. Findling, K. D. Pelle, Greenwood, Westport.

Yardley J., China 's Leaders Try To Impress and Reassure the World, „The New York Times”, 8.08.2008, http://www.nytimes.com/2008/08/09/sports/olympics/09china.html?th\&emc=th, 16.10.2012.

\section{Sports policies as a result of political confrontation between states}

\section{Summary}

The paper is dedicated to the issue of the relations between sport and politics. Its aim is to explore examples of connections between sport and politics in the situation of conflicts between states. An attempt was made to indicate the ways in which political rivalry is transferred to the world of sport, as well as the aims of the states and the determinants of their actions.

The analysis encompasses the following ways in which sport is used politically: competition in the Olympic Games medal ranking, desire to win prestigious contests, hosting sports events, participating in international sport and sports boycotts.

As a result of the research, it was observed that assigning political meaning to sport in situations of political confrontation between states is connected either to the desire to enhance a nation's prestige, or to hit other actors in international relations. It was also observed that non-democratic states particularly often use sport for political reasons.

Key words: politics in sport, sport, politics, political confrontation 